\title{
Textual Variants and Textual Criticism in the WORKS OF RABBENU TAM: BETWEeN THEORY AND

\section{Avraham (Rami) Reiner}

\begin{abstract}
Rabbi Jacob ben Meir, better known as Rabbenu Tam (11001171), is famous for his radical interpretations of the Talmud and his influence in matters of Halakhah. Less well known is his abiding interest in the textual transmission of the Talmud and its manuscripts. Rabbenu Tam was well aware of the redactional layers within the Talmud, and in many instances, claimed that certain sentences were a later addition to the Talmud inserted by students and copyists over the generations. As a result, Rabbenu Tam did not hesitate to challenge the binding legal authority of those accretions. The introduction to Rabbenu Tam's Sefer ha-yashar argues that the received text of the Babylonian Talmud was corrupt and that the text had been influenced by glosses suggested by Rashi and other sages. In his opinion, textual corrections ought to be raised in the context of commentaries and not inserted within the Talmud itself. This article will describe the relationship between the principles proposed in the introduction to Sefer ha-yashar and Rabbenu Tam's actual engagement with the talmudic text in his exegesis.
\end{abstract}

\begin{abstract}
I have called this book Sefer ha-yashar [lit., The book of the straight] because I have made all of the precepts straight therein - the original teachings and versions of books, as they were. ${ }^{1}$
\end{abstract}

With these words, Rabbenu Tam ${ }^{2}$ begins his introduction to Sefer ha-yashar, declaring that his work will be devoted to "straightening out" the teachings and

Many thanks to Prof. Joshua Levinson for his sensitive reading and articulate comments, and to Elli Fischer for translating this article.

1. Sefer ha-yashar, Novellae, ed. Shimon Shlomo Schlesinger (Jerusalem: n.p., 1959), introduction, p. 9. Translation ours.

2. Rabbenu Tam (1100-1171) is Rabbi Jacob ben Meir, whose maternal grandfather was Rashi, and who was the first of the Tosafists active in France and Germany in the twelfth and thirteenth centuries. For a description of his personality and literary oeuvre, see Isaac Hirsch Weiss, "Toledot Rabbenu Tam," Beit Talmud Vienna 3ff (1883): 33-36, 129-38, 161-69, 193-201, 225-33, 257-61, and 289-95; Avigdor Aptowitzer, introduction to Sefer Ra'avyah (Jerusalem: Mekize Nirdamim, 1938), 270-72, 357-66; Ephraim Elimelech Urbach, The Tosafists [in Hebrew] (Jerusalem: Mosad Bialik, 1980), 60113; Haym Soloveitchik, Yeinam (Jerusalem: Maggid, 2016), 6-12; Avraham (Rami) Reiner, "Rabbenu Tam: Rabotav (Ha-Zarfati'im) ve-talmidav bene 'Ashkenaz" (MA thesis, Hebrew University of Jerusalem, 1997); Reiner, "Rabbenu Tam and His Contemporaries" [in Hebrew] (PhD diss., Hebrew University, 2002). Rabbenu Tam wrote Sefer ha-yashar in the 1140s. In its introduction, he declared that his book would deal with the preservation of the text of the Talmud, and he sharply opposed 
text of the Talmud. However, the book accomplishes much more than the goals set in this declaration. While it contains numerous treatments of the correct text of talmudic passages, it also incorporates fragments of commentary, halakhic monographs, and numerous responsa. Its attention to textual matters is thus a very small portion of the book as a whole.

In contrast, the introduction to the work can stand alone as a wide-ranging manifesto in which the author discusses the proper methods and the exigencies of how to treat the text of the Talmud, in an era when the dissemination of a work was dependent on manuscripts, the habits of copyists, and the conduct of its readers. In this article, I will focus on just one element of the vast wealth of material that awaits those who study this introduction, namely, Rabbenu Tam's criticism of those who emend the text of the Talmud itself: "It is not enough that [those who emend the text] corrupt texts that seem to be glosses, but they even [corrupt] the words of the Amoraim and Tannaim themselves; this is inconceivable for anyone who fears God."3

For the purposes of this article, the most important aspect of this passage is $\mathrm{R}$. Tam's distinction, articulated as an offhand philological remark, between "texts that seem to be glosses" (ha-nir'in perush) and "the words of the Amoraim and Tannaim themselves." The conscious differentiation between the dicta of talmudic sages and "glosses"-interpolations that explain, translate, or interpret a word or phrase - did not originate in R. Tam's academy; his grandfather, Rashi, preceded him in this regard. ${ }^{4}$ Nor did it end with him; in the hands of the later Tosafists, this technique developed into a method that reached its fullest expression in the academy of Nahmanides. ${ }^{5}$ However, whereas R. Tam's predecessors maintained that after identifying a gloss as a late addition it should be emended or deleted from the text, R. Tam's view was that the student has no right to excise those "texts that seem to be glosses." His words imply a forgiving attitude toward such

contemporary scholars and earlier scholars who emended the text of the Talmud for various reasons. The present article discusses the contents of this introduction in comparison with the practices of Rabbenu Tam himself. It is one chapter of a work in progress on Rabbenu Tam and his methods.

3. Sefer ha-yashar, Novellae, introduction, p. 9.

4. For a list of examples of this phenomenon in Rashi's commentary, see: A. Aptowitzer, "Shibolim-Hosafot ba-Talmud ha-Bavli," Ha-zofeh le-hokhmat Yisra'el 4 (1915): 17. See ad loc. the references to Yoma 4b, s.v. man de-amar, where Rashi wrote: "This was added for no reason, and there it was a gloss in the books, so that you do not ask later"; Bezah 34b, s.v. be-devar: "It is an extraneous formulation, and it is the gloss of mukzeh that was written in the books"; and other comments like this. For additions to Aptowitzer's list, see David Rosenthal, "La" 'itparesh lan may ba'i hakha": On Foreign Bodies in the Bavli" [in Hebrew], Bar Ilan 18-19 (1981): 151nn8-11. An excellent example is the one brought from Rashi's commentary to Keritot 4a, s.v. ve-hakha": "This version, which is written in the books, is corrupt. It was written by mistaken commentators who were not proficient in this passage, so they glossed it erroneously in the text."

5. See Shamma Friedman, "Perek Ha-'ishah Rabbah in the Bavli, with a General Prolegomenon on the Study of the Sugya" [in Hebrew], Mehkarim u-mekorot 1 (1978): 287-93, and references to earlier studies. See also Yaakov Shmuel Spiegel, "The Language of Later Interpretation and Additions" [in Hebrew], Téudah 3 (1983): 91-112. 


\section{Textual Variants and Textual Criticism in the Works of Rabbenu Tam}

deletions ex post facto, but that the prohibition on performing such excision-with a sharp knife or metal scraper-remains in force.

A long-standing scholarly tradition portrays Rabbenu Tam as a figure who did not live up to his own standards with regard to these emendations. Thus, for example, Isaac Hirsch Weiss wrote:

But let us see whether R. Jacob himself did as he commanded others to do. If we attend to his Tosafot, we will find that he, too, in many places emended the text of the book before him. Moreover, he occasionally made hasty and logically weak emendations.... So it is very surprising that Rabbenu Tam made such a to-do about this matter, given that he himself recognized that sometimes even he had to emend his book and delete some variants. Yet there is no end to the harsh words he spoke against those who emend books, and the contempt and wrath he spewed at them. ${ }^{6}$

So, too, in his introduction to Sefer Ra'avyah, Avigdor Aptowitzer wrote:

We see an inconsistency in the view of R. Tam: He curses and lambastes those who make emendations, yet he himself frequently emended. He derides and insults those who engage in mental gymnastics [pilpul], but his own acuity often approximates mental gymnastics. It is certainly possible to distinguish between one emendation and another, and between one example of mental gymnastics and another, but this exercise itself borders on mental gymnastics. R. Meshullam bar Nathan was certainly no shallow individual who would treat the Talmud frivolously, emending and changing the text on a whim without need and without being compelled by reason. And Rabbenu Tam himself says, "When the Talmud, in one place, says 'obligated' and elsewhere, 'exempt,' I answer it well." Is there any greater example of mental gymnastics? Certainly his intentions were good and his actions correct according to the view that the Talmud is all of one piece and was molded at one time, such that it is impossible for there to be contradictions, discrepancies, imperfections, and cracks; that it must be made straight, free of rough edges. But why did it not even occur to him that others, too, might have noble intentions? One who is intellectually honest will not begin with these constraints and contrivances in order to vindicate R. Tam from this inconsistency. ${ }^{7}$

Ephraim Elimelech Urbach summed up in brief:

All we have are the sources, and they provide us the material with which to describe this figure; if they show contradictions and internal conflicts, then that is how the man was. ${ }^{8}$

6. Weiss, "Toledot Rabbenu Tam," 136-37. Translation ours.

7. Aptowitzer, Ra'avyah, 359. Translation ours.

8. Urbach, Tosafists, 60. Translation ours. 
The present study will demonstrate that Rabbenu Tam was, in fact, perfectly consistent in mediating the tension between his sweeping and vehement opposition to effacing the text as it was and his recognition of the inevitable necessity of occasionally making emendations in the text of the Talmud. Moreover, as we will see, his opposition to deleting anything from the text itself was rooted in his view that many of the accreted glosses and suggestions of students and copyists, from the era of the Amoraim to the medieval era, calcified and became part of the canonic text of the Talmud itself.

There is no doubt that R. Tam's opposition to excising snippets that were identified as exegetical additions produced complications. On one hand, he did not, as stated, permit the emendation of the body of the text, but on the other hand, he took the exegetical liberty of explaining what he identified as "the words of the Amoraim and Tannaim themselves" differently from the glosses to the Talmud text. Faced with such situations, R. Tam developed a way to both preserve the text while also identifying segments as glosses, thus legitimating the disregard of their substance and even their halakhic implications.

Let us demonstrate this with a passage from B. Hagigah $3 \mathrm{~b}$ :

There was an incident involving Rabbi Yose ben Durmaskit, who went to greet Rabbi Elazar in Lod.

[R. Elazar] said to him: What novel idea was taught today in the study hall? [R. Yose] said to him: [The sages] voted and concluded that [residents of the lands of] Ammon and Moab separate the poor man's tithe during the Sabbatical year.

[R. Elazar] said to him: Go tell them: Do not be concerned about your vote; this is the tradition that I received from Rabban Yohanan ben Zakkai, who heard from his teacher, and his teacher from his teacher-a halakhah transmitted to Moses at Sinai: In Ammon and Moab one separates the poor man's tithe in the Sabbatical year.

Why? Many cities were conquered by those who ascended from Egypt but were not conquered by those who ascended from Babylonia, because the first consecration [of 'Erez Yisra'el] sanctified it for its time but not for the future, and [those who ascended from Babylonia] left [those cities aside and did not reconsecrate them] so that the poor could rely upon [its produce] during the Sabbatical year.

According to R. Elazar, the halakhah transmitted to Moses at Sinai (halakhah le-Moshe mi-Sinai) was that those who dwell in the regions of Ammon and Moab are commanded to separate the poor man's tithe during the Sabbatical year. A rationale is offered for this "halakhah transmitted to Moses at Sinai," namely, that the Transjordanian regions of Ammon and Moab were sanctified in the "first consecration," that is, the conquest of Joshua, but not in the "second consecration" that transpired at the time of Ezra's migration. The first consecration was "not consecrated for the future," so there is no obligation whatsoever to tithe the produce of these regions. Nevertheless, the sages imposed an obligation to give the paupers' tithe, to provide for the welfare of the poor. 
This explanation also implies that in those places that Joshua did not conquer, that is, regions that are neither in nor adjacent to 'Erez Yisra'el, there is no obligation to give tithes. This implication, however, contradicts Rabbenu Tam's basic position that, according to Halakhah (albeit not as practiced), terumah and tithes must be given even outside of 'Erez Yisra'el, regardless of the halakhic significance of the "first" and "second" consecrations. ${ }^{9}$ To escape the implications of this passage, R. Tam wrote:

\begin{abstract}
Ammon and Moab likewise, due to the reliance of the poor, the pauper's tithe was instituted during the Sabbatical year, but not the second tithe. This is also evident from the end of tractate Yadayim, which teaches: "Ammon and Moab give the pauper's tithe in the Sabbatical year" without offering a reason. And the reason given in Hagigah, "many cities ...," was not stated by R. Elazar, but by the author of the Talmud [baial ha-Talmud]. One cannot infer from here to R. Elazar['s own opinion]. ${ }^{10}$
\end{abstract}

According to R. Tam, the explanation of the law transmitted to Moses at Sinai, beginning with "Why?" does not represent the words of R. Elazar himself, but the words of the "author of the Talmud." R. Tam found support for his claim in a mishnah in tractate Yadayim, where the law appears without this explanation. That being the case, R. Tam preferred his own understanding of the tannaitic law that "in Ammon and Moab one separates the poor man's tithe in the Sabbatical year" to the one that originated in the academy of the "author of the Talmud." There is no erasure of text, but there certainly is a differentiation between the basic halakhah and its explanation, and the exploitation of this division in order to dispute both the theoretical basis and the halakhic conclusions of a talmudic passage.

Another example: B. Ketubbot $31 \mathrm{~b}$ addresses the appropriate punishment for stealing on the Sabbath. The principle that drives the passage is kim leh be-derabbah mineh (the more severe suffices for him). According to this principle, one who committed two transgressions with one act is subject only to the more severe punishment. A baraita that appears in this passage asserts, "One who steals a wallet on the Sabbath is obligated [to repay], because he was already liable for stealing before he violated a prohibition punishable by stoning. If he was dragging it out, he is exempt [from payment], for the violation of the Sabbath and the theft are simultaneous." When one commits a theft on the Sabbath by dragging something from the owner's property into the public domain, the violation of the Sabbath (transporting something from the private domain to the public domain) and the act of theft (bringing the stolen object

9. See Tosafot to Avodah Zarah 58b, s.v. bazar; Hullin 6b, s.v. ve-hitir. Although R. Tam asserted that there is an obligation to separate tithes outside the Land of Israel, he defended the custom of not taking tithes with the claim that the lands are mortgaged to the payment of royal taxes, and therefore there is no obligation to tithe their produce. See also: Sefer ha-yashar, Responsa, ed. Shraga Rosenthal (Berlin: Itzkowsky, 1898), §45:5, p. 83, where R. Tam mentions this as an issue that one should not be stringent about, even though the Halakhah is stringent in principle.

10. Sefer ha-yashar, Novellae, §437, p. 257. 
into the thief's possession) occur at the same time. In accordance with the principle of kim leh be-derabbah mineh, only the capital punishment incurred by Sabbath desecration applies.

However, the Talmud has difficulty finding a situation in which these two transgressions are violated simultaneously, for if the thief dragged the stolen object into the public domain, he has not acquired it, because there is no acquisition in the public domain. Alternatively, if he dragged it into a private domain, he has not desecrated the Sabbath. To resolve the problem, Rav Ashi proposes the following: "He linked his hands below three [handbreadths] and received it, and in accordance with Rava, for Rava said: A person's hand is considered like four [cubits] by four [cubits of land]." According to Rashi, Rava's words, "a person's hand," were said with regard to putting things down on the Sabbath. R. Ashi uses this principle to assert that just as with respect to Sabbath violations a person's hand is considered a space where things can be placed, so too, with respect to acquisition "it is as though he lifted it up," in Rashi's words.

The Tosafists found Rashi's explanation to be problematic. ${ }^{11}$ According to them, there should be no connection between the definition of a space for the purposes of the laws of the Sabbath and that of a space that enables acquisition. Moreover, the fact that a person's hand acquires on his behalf is a trivial principle that does not need support from Rava's statement, which was initially said with regard to the laws of the Sabbath. To resolve these problems, R. Tam, ignoring part of the text, suggests (ad loc.), "R. Tam's version does not have, 'for Rava said: A person's hand is considered,' but only, 'in accordance with Rava'; nothing more." According to R. Tam, the original passage referred only to Rava and did not mention any substantive statement. Only at a later stage were Rava's words, "A person's hand is considered like four by four," introduced. In R. Tam's view, this explanatory reference is a mistake, and the passage actually had a different statement of Rava's in mind. ${ }^{12}$ As in the earlier example, here, too, R. Tam differentiated between the basic talmudic assertion, "in accordance with Rava," and its interpretation, which included an erroneous reference. For our purposes, it is significant that, in contrast to the first example, in which R. Tam identified the source of these additions as the "author of the Talmud," here R. Tam mentions neither the author of the explanation nor when he lived: Was it one of the "authors of the Talmud" or a copyist from a later era? ${ }^{13}$

11. B. Ketubbot 31b, s.v. Rav Ashi.

12. Based on what appears in the aforementioned passage from Tosafot, R. Tam maintains that the Talmud's original reference was to Rava's statement in B. Shabbat 92a: "Binding with the hand is not considered binding." However, in this source, as it appears in all extant manuscripts, there is no dictum of Rava's that asserts that "binding with the hand is not considered binding," even though such a conclusion is warranted by implication.

13. With respect to this example, see also Avraham Weiss, Le-korot hithavut ha-Bavli (Warsaw: Ha-hevrah le-hafazat mada'e ha-Yahadut be-Polaniyah, 1929), 5: "R. Tam's idea is of particular value for the problem of the Bavli's formation"; David Rosenthal, "On Abbreviation and Its Supplementation: A Chapter in the Redaction of the Babylonian Talmud" [in Hebrew], Mehkere Talmud 3 (2005): 831-32. See also p. 833 ad loc. for another example from R. Tam. 
A third example: In B. Nedarim 19a, the Talmud compares the law stated in the Mishnah, "Uncertainties regarding vows are [treated] stringent[ly]" with another tannaitic source that states, "Liquid about which there is uncertainty whether it became unclean - is [itself] unclean. But as for rendering something else unclean - it [remains] pure. These are the words of Rabbi Meir, and Rabbi Elazar would say likewise." The source of this passage is the Tosefta (T. Teharot 5:10), and R. Tam wondered why the author of this passage asked a question based on the Tosefta when he could have cited a mishnah (Teharot 4:9) that states simply: "Liquid about which there is uncertainty whether it became unclean -is [itself] unclean." In a brief comment in Sefer ha-yashar, R. Tam posits that the shorter mishnah in Teharot, not the corresponding Tosefta passage, appeared in the "original" Nedarim passage. He explained how the longer Tosefta passage entered the discussion as follows: "Disciples wrote the baraita of the first chapter of Pesahim, where it is taught thus, in order to challenge this passage, and scribes mistakenly wrote it inside [the text]." ${ }^{14}$ That is, $\mathrm{R}$. Tam argues that a passage in B. Pesahim (16a) addresses the longer Tosefta passage, which ascribes the rulings to R. Elazar and R. Meir. In contrast, the Nedarim passage at the center of our discussion had no need for that additional information; for its purposes, it quoted only the mishnah that states "liquid about which there is uncertainty whether it became unclean-is [itself] unclean." Students who noticed the similarity between these subjects and passages copied the Tosefta passage and the ensuing discussion in B. Pesahim, in the margins of their Nedarim texts, to serve as a sort of reference for the purposes of their own studies. The students' books, which contained only the original laconic mishnah in Teharot in its main text, and which contained the Pesahim passage, including its citation of the Tosefta, in its margins, reached the hands of scribes who attempted to integrate the marginalia into the main text they were copying. Thus, the lengthier, more complicated Tosefta passage made it into the text of B. Nedarim, replacing the shorter line from the Mishnah, which was perfectly adequate for the purposes of that discussion.

Unlike the first two examples, this one is not about interpretive clauses that were added to an earlier dictum. However, like our earlier examples, here, too, R. Tam uses literary and philological tools to identify segments that were added to the Talmud at a later stage. Rabbenu Tam identified a marginal note, a gloss, of those who copied and studied the passage over the course of the generations. It is not attributed to the "author of the Talmud" as the earlier examples; this time, R. Tam attributes the additions to copyists of Talmud manuscripts, who merged what they found in the margins of the books they copied into the main part of the books they produced. ${ }^{15}$

14. Sefer ha-yashar, Novellae, §74, p. 60.

15. This example was first addressed in Yehuda Feliks, "Rabbi Jacob b. Meir (Rabbenu Tam)'s Sefer Ha-yashar: Structure, Content, Method, and Sources" [in Hebrew], Sinai 39 (1959): 179. See also Urbach, Tosafists, 687. In MS Moscow-Gunzburg 1134 of B. Nedarim, M. Teharot indeed appears, rather than T. Teharot, as R. Tam surmised. In contrast, the text of MS Vatican 110 is similar to the one that appears in the printed Talmud and the version that $\mathrm{R}$. Tam had. On the transition from the 
A fourth and final example: One of R. Tam's most dramatic and controversial innovations was based on this type of reading. Most medieval halakhists maintain that any amount of hamez (leavened grain, which is prohibited on the festival of Passover), even a trace amount, renders a mixture forbidden. R. Tam, however, rules permissively regarding a mixture that contains hamez, as long as the hamez component in the mixture is less than one-sixtieth of the total. This permissive ruling relies on R. Tam's identification of the words "in any amount, in accordance with Rav," in the sentence, "The law is: hamez, at its time [of prohibition], whether [in a mixture] with its kind or with [things that are] not its kind, is forbidden in any amount, in accordance with Rav" [Pesahim 30a], as words that were added to the talmudic dictum by someone familiar with the compilation Halakhot Gedolot, which was attributed by medieval French scholars to the eighth-century Yehudai Gaon. As Rabbenu Tam put it:

\begin{abstract}
Error-prone exegetes wrote this based on Halakhot Gedolot. Evidence that this is the case is that Halakhot Gedolot states: "Rava said, the law is: hamez on Pesah, whether [in a mixture] with its kind or with [things that are] not its kind, is forbidden. The fact that it assigned no measure to this matter means to say that [it is forbidden] in any amount, in accordance with Rav." Thus, "in any amount, in accordance with Rav" was not in the books. Rather, apparently Rabbi Yehudai [the presumed author of Halakhot Gedolot] ruled thus, and as a result, this is how things were written in the new books. ${ }^{16}$
\end{abstract}

Rabbenu Tam's demonstration is as follows: Halakhot Gedolot states that since the Talmud's discussion makes no assertions about the quantity that renders the mixture forbidden, it is clear that the mixture is rendered forbidden by any quantity of hamez, even the tiniest amount. In the words of Halakhot Gedolot: "The fact that [the Talmud] assigned no measure means that [it is forbidden] in any amount, in accordance with Rav." R. Tam derived from this passage that " in any amount, in accordance with Rav' was not in the books [of the Talmud]" and that "apparently Rabbi Yehudai ruled thus, and as a result, this is how things were written in the new books."

Rabbenu Tam's argument, and all the more so his subsequent ruling, provoked a major controversy at that time. (Simcha Emanuel has made an important contribution to our understanding of one side of this controversy. $)^{17}$ For our purposes, the important point is that in every instance surveyed, R. Tam identified

oral transmission of the Talmud to manuscript transmission, and on the role of France and Germany in this process, see Talya Fishman, Becoming the People of the Talmud (Philadelphia: University of Pennsylvania Press, 2012), 121-54. However, see U. Fuchs, The Geonic Talmud: The Attitude of the Babylonian Geonim to the Text of the Babylonian Talmud [in Hebrew] (Jerusalem: Herzog Academic College, 2017), 48-81.

16. Sefer ha-yashar, Novellae, §471, p. 281.

17. Simcha Emanuel, "A Responsum of Rabbi Samuel ben Ali, Gaon of Baghdad, to the Sages of France” [in Hebrew], Tarbiz 66 (1997): 93-100. 


\title{
Textual Variants and Textual Criticism in the Works of Rabbenu Tam
}

units that appeared in his Talmud as being later addenda to the primary text of the Talmud. Once he made this differentiation, he did not hesitate to offer new interpretations of the talmudic dicta themselves, and, as we saw in the last case, even to render novel halakhic rulings on the basis of his new interpretation, while ignoring the interpretation or ruling that appears in the extant copies of the Talmud.

In all of these cases, there is no indication that $\mathrm{R}$. Tam emended the text of the Talmud. According to R. Tam, he was following the policy of his grandfather, Rashi:

\begin{abstract}
Even Rabbi Solomon, if he emended the text, he emended it in his commentaries, but he did not make emendations in his copy [of the Talmud]. Rather, his disciples made emendations on the basis of his commentaries, something that he did not dare to do in his lifetime, except in tractate Zevahim. ${ }^{18}$ I examined [and found] that his books were not emended in his handwriting. And this stands to reason: If a person does not know the Halakhah, he should write its interpretation as he sees fit, if he wishes. However, he should not delete from the books, for the words of Torah are meager in their place but rich in another place, and if it seems empty, it is from him $^{19}$ [i.e., it is he who is empty]. ${ }^{20}$
\end{abstract}

It emerges from all of these examples that in Rabbenu Tam's view it is legitimate for a scholar to suggest emendations of the talmudic text as long as he does not tamper with the text of the Talmud itself.

This very issue was the central point of R. Tam's polemic against Rabbi Meshullam of Melun in the 1150 s. $^{21}$ Close scrutiny of R. Tam's words shows

18. Regarding the attribution of part of the print version of Rashi's commentary to B. Zevahim, see Abraham Berliner, "Toward a History of Rashi's Commentaries" [in Hebrew], in Sefer Rashi, ed. J. L. Maimon (Jerusalem: Mosad Harav Kook, 1957), 139 and n. 22. On the uniqueness of Rashi's mode of operation in this tractate, see Israel Ta-Shma, Rabbi Zerahiah Halevi and His Circle: Rabbinic Literature in Twelfth-Century Provence [in Hebrew] (Jerusalem: Mosad Harav Kook, 1993), 97n2. See also: Yaakov Shmuel Spiegel, Chapters in the History of the Hebrew Book: Scholars and Their Annotations [in Hebrew] (Ramat Gan: Bar-Ilan University, 2005), 138 and n. 39. See also Responsa Rashi, Israel Elfenbein edition (New York: Shulsinger Brothers, 1993), §24, p. 19:

The text in [the chapter] "Ezehu Mekoman" [B. Zevahim 50b], of which you wrote in your question that it is written in books ... and in some it is written ... and the entire matter has been emended. I thought, perhaps I wrote this on my own, so I examined a different page on which I copied glosses from this tractate from the book of Rabbenu Isaac b. Judah [Rashi's teacher], and from which I emended my exemplar. I saw that the space was blank, and I don't know whether I found it blank or whether I left it blank because I didn't understand them. Now, please examine [the book of R. Isaac b. Judah] and let me know, my friend.

For an interpretation of this passage, see Spiegel, History of the Hebrew Book, 120-21 and n. 50. Either way, it clearly emerges from these words that Rashi emended the main text of his Talmud in Zevahim, to the point that he could not find what had been written there prior to his emendations.

19. Y. Pe'ah 1:1, interpreting Deut 32:47.

20. Sefer ha-yashar, Novellae, $\$ 9$.

21. Regarding this controversy, see Avraham (Rami) Reiner, "Commentary and Halakhah: A New Look at the Controversy between Rabbenu Tam and R. Meshullam" [in Hebrew], Shenaton 
that his anger at R. Meshullam was mainly because of his suspicion that the latter had emended the text of the Talmud itself: ${ }^{22}$ "For when they don't know, they mislead the world, and when they are confounded, they emend the books. But you are worse than them, for they write ' $\mathrm{HG}$ ' [= hakhi garsinan, which means "this is our reading"] before their emendations, so their work is discernable. It is not so with you; rather, you do not indicate your emendations, and others rely on you and are misled. Moreover, they emend one or two words, whereas you [emend] twenty-two." Rabbenu Tam's central claim was that R. Meshullam emended the books themselves, to the point that the reader cannot distinguish the original text from the emendations. It is true that $\mathrm{R}$. Tam also criticized the flippancy with which R. Meshullam and others like him emended the Talmud, but the main thrust of his polemic was directed at emendations made in the main text of exemplars of the Talmud itself. R. Meshullam responded, "Yet I am steadfast that I have never erased from a book. Rather, I study your variant, and then I show them my variant, and some write it in a notebook." R. Meshullam thus understood - and may even have agreed with—R. Tam's primary opposition, which was to emendation of the talmudic text without leaving indication of having done so. This comports with the examples addressed above.

In each of the examples cited, R. Tam identifies a part of the text that was added at a later stage. However, these additions are attributed to different eras and can therefore shed light on R. Tam's thinking about the genesis of the talmudic text. In the fourth example above, the source of the words in the Talmud, "in any amount, in accordance with Rav," were identified by R. Tam as originating from Halakhot Gedolot, under whose influence "error-prone exegetes wrote." 24 Likewise, in the third example, about "uncertainties regarding vows are [treated] stringent[ly]," R. Tam identified the addition as a student's marginal gloss that was later integrated into the main text. ${ }^{25}$ His interpretation, like the one discussed before it, reflects an awareness of an existing Talmud, into which errors and emendations creep as part of the processes by which written material is transmitted and studied.

In contrast to these cases, when $\mathrm{R}$. Tam addresses the first case, "Ammon and Moab separate the poor man's tithe during the Sabbatical year," he attributes what he identifies as an addition to the "author of the Talmud" (bac $a l$ ha-Talmud). ${ }^{26}$ This expression, which appears frequently in R. Tam's writings, refers to one of the sages responsible for the particular talmudic passage- - sometimes its redactor and sometimes the Amoraim named in the discussion. Thus, in

ha-mishpat ha- ivri 21 (1998-2000), 207-39, and in the references to prior studies cited there. See also: Fishman, People of the Talmud, 144-47.

22. Sefer ha-yashar, Responsa, §50, p. 105.

23. Ibid., §47:7, p. 93.

24. Sefer ha-yashar, Novellae, §471, p. 281.

25. Ibid., §74, p. 60.

26. Ibid., §437, p. 257. 
his treatment of B. Shabbat $101 \mathrm{~b}$, R. Tam wrote: $:^{27}$ "The mishnah is not thus. Rather, it is typical of the Talmud to expand on it [according to] what it knows of its interpretation ... and the author of the Talmud, within this expanded interpretation, teaches us."

Taken together, we see that Rabbenu Tam identified additions to the Talmud from several different eras and thus that he viewed these additions as part of a prolonged process that characterized the production of the Talmud in its entiretybeginning in the first generations of Amoraim, whose explanations became an integral part of the Talmud, and extending all the way to the medieval era, to the addenda of students and copyists who tinkered in the margins and tampered with the main text. R. Tam related to such addenda again at the end of his introduction to Sefer ha-yashar, where he wrote: ${ }^{28}$

Now I will write to you of the additions that they made in order to change the
face of the matter in the interpretation of Halakhah. All these glosses were
made because they did not know the interpretation of the passage. Yet, I
will not object to them because they were not deleted from the Talmud. But
one who makes emendations because he disagrees with the rationale of the
Talmud, to him I apply the dictum: "One who says: "This teaching is good,
but this one is not' will destroy the riches of Torah." 29 God forbid. Lest he
be condemned to weariness of body because of the sin of excessive study. ${ }^{30}$

The "additions that they made in order to change the face of the matter in the interpretation of Halakhah" are, in my opinion, those same additions that we surveyed above - additions made to the Talmud because students did not understand the passage. Yet Rabbenu Tam does not object to these because they had already penetrated the text of the Talmud and became part and parcel thereof. One may suggest an alternative interpretation to these additions, and even deny that the interpretations implied by these additions are authoritative. However, according to R. Tam, one may never "object to them," that is, emend or delete them, "because they were not deleted from the Talmud." Even a segment that was added to the Talmud at a later stage is canonized, as it were, from the moment it is absorbed into the written talmudic text, and it cannot be erased from the text of the Talmud. ${ }^{31}$

A responsum of R. Isaac of Dampierre, the nephew and disciple of R. Tam, offers insight into how $\mathrm{R}$. Tam dealt with passages that he would not delete but believed should be emended, "I examined R. Tam's [copy of] the order of Kodashim, and I saw that it is written therein 'the law is in accordance with the sages,'

27. Ibid., \$276, p. 170 .

28. Sefer ha-yashar, introduction, 10. This part of the introduction appears only in MS Oxford of Sefer ha-yashar.

29. B. Eruvin $64 a$.

30. Ecclesiastes 12:12.

31. For a different interpretation of this passage, see Spiegel, Chapters, 135. 
and he made horns [karnayim] to indicate that this is an error, and that 'the law is in accordance with the sages' should not be part of the text." ${ }^{, 32}$

Rabbenu Tam thus tampered with the text of his own books, but this tampering, the marking with "horns," allowed for clear differentiation between the text that was initially in the book and R. Tam's suggested emendation. This is consistent with his remarks to R. Meshullam of Melun seen above. It stands to reason that R. Tam, who objected, in many and varied places, to any tampering with the text found in books, applied this method consistently. The attestation of R. Isaac can be generalized: in every case where we find attestations that $\mathrm{R}$. Tam emended his books, the meaning is not that he deleted any part of the text, but that he made a discernable change, by using "horns" and other graphic symbols that prevent one from ignoring the problematic, rejected text, yet enable a future reader to preserve the old version alongside the suggested emendation.

Another attestation of R. Isaac is similar: "In a book containing [the orders of] Yerushalmi Zera im and Mo'ed that belonged to Rabbenu Jacob [= R. Tam], it is written, at the beginning, that R. Asi said, etc., as I have written. It seems to be the writing of R. Solomon, the son of R. Jacob. At the end of the passage, our master [=R. Tam] wrote, in his own handwriting, which is familiar to me: 'This is the custom everywhere." ${ }^{33}$ Regardless of whether R. Solomon was the copyist of his father's entire Yerushalmi volume or only glossed specific words, the key point is that when R. Tam added something to this volume, R. Isaac could identify that it was in a different handwriting.

Thus, R. Tam cautioned against changing the text of the Talmud itself without leaving any trace of what was there before. His instruction was very simple: Alternative suggestions may appear in the margins of manuscripts of the Talmud, as long as they are distinct from the older version, whose clear and unambiguous presence will persist. To that end, R. Tam used the aforementioned "horns"; it stands to reason that he indicated additional suggested emendations in a similar way. The "horns" should therefore be viewed like parentheses in printed texts, and it is reasonable to presume that other symbols indicated other insights.

The many instances in which there is documentation that R. Tam emended or erased the Talmud text should therefore be seen as instances in which he "glossed" the text of his Talmud in a way that preserves the old text alongside the newly proposed version. These are not deletions that erase all trace of what came before, but glosses that say what they say while enabling the rejected version to persist in the sight of the glossator. ${ }^{34}$ This policy may be implicit in

32. Responsa of R. Isaac b. Samuel, R" i Ha-zaken, P. Roth and A. Reiner edition (in press).

33. Ibid., $\$ 2$.

34. There are dozens of instances in which R. Tam addresses textual questions, and it is impossible to know how he executed the emendations technically. See also: (A) Sefer ha-yashar, Responsa, $\S 70: 2$, p. 165: "Regarding the rash oath [shevi'at bituy], I restored it to its former state and I wrote it in my book [of the Talmud]. It is also evident from Shavu'ot that the deleted version is primary"; (B) Tosafot on Shabbat 107b, s.v. yesh: "Some books have ... and this is a corruption ... and R. Tam likewise deleted it from his book"; (C) Tosafot on Shabbat 110a, s.v. Rav Yosef: "R. Tam deleted this entire 
R. Tam's letter to R. Meshullam: "Do not be angered by my words, for I said to our masters, face to face, that it should be decreed against some of them that they not convene a yeshiva. For when they don't know, they mislead the world, and when they are confounded, they emend the books. But you are worse than them, for they write ' $\mathrm{HG}$ ' before their emendations, so their work is detectable. It is not so with you; rather, you do not indicate your emendations, and others rely on you and are misled." ${ }^{35}$ Suggested emendations are undesirable, but sometimes they are unavoidable. What $\mathrm{R}$. Tam forbade completely, and what he deemed unconscionable, was making a proposed textual emendation into a part of the text itself, not merely a suggestion in a commentary or in the margins. Only when the old text is completely effaced and a new one takes its place does R. Tam use the bans of Rabbenu Gershom and attack R. Meshullam and those like him.

The words from R. Tam's introduction to Sefer ha-yashar, "And this stands to reason: If a person does not know the Halakhah, he should write its interpretation as he sees fit, if he wishes. However, he should not delete from books," are clear. ${ }^{36}$ Suggested emendations, when warranted, were precisely delimited and indicated by various graphic symbols. Their role could be ascertained only once the wellsprings of commentary had been dredged.

The scholarly tradition briefly summarized above - the tradition of Weiss, Aptowitzer, and Urbach - became enthralled, in my opinion, by the turbulent, fascinating, self-contradictory, and somewhat aggressive figure of R. Tam. Indeed, there is no doubt that the figure of Rabbenu Tam has all the components that make for a compelling character. Ultimately, however, a figure whose impact on the history of Halakhah was so significant and decisive cannot be explained solely through a description of his psychological traits. ${ }^{37}$ In this article, along

matter from his book and said that it is not part of the text except at the beginning [of the chapter] "Elu 'ovrin"; (D) Tosafot on Eruvin 38b, s.v. 'amar: "R. Tam deleted de-tanya from his book because it is stated at the beginning of [B.] Bezah"; (E) Tosafot on Bava Batra 166b, s.v. nikhnas: "I found in R. Tam's book, in M. Keritot ... and that originally it had 'and the rest is not obligatory' but [R. Tam] deleted it. This would seem correct, but it is surprising, for it is written in all the books, whether of Keritot, or of Torat Kohanim, or here"; (F) MS Montefiore 65, p. 101a (and the corruption of it in Tosafot of Rabbenu Judah b. Rabbi Isaac of Paris on Tractate Avodah Zarah, Moshe Yehuda Blau, ed., in Shitat Ha-kadmonim 'al masekhet Avodah Zarah, vol. 2 [New York: S. Deutsch, 1969], 325): "Our master saw that in the book of R. Tam, he had deleted the vav of ve-lokin [and] ve-'en lokin"; (G) Tosafot Rabbenu Elhanan 'al masekhet Avodah Zarah (Bene Berak: A. Y. Kroyzer, 2003), 153: "Rabbi Jacob [R. Tam] deleted tiyuvta from his book there and wrote in a responsum there that books written before [4]788 [1028] did not have tiyuvta"; (H) Tosafot to Sukkah 34b, s.v. she-tehe: "R. Tam emended his book"; (I) Tosafot to Niddah 73a, s.v. tanna de-vei Eliyahu: "Some books do not have this text, however, it is in Rashi's commentary, and Rabbenu Tam emended his book, and it also stands to reason." I thank my brother-in-law, Prof. Joshua Levinson, for calling my attention to this last source.

35. Sefer ha-yashar, Responsa, §50, p. 105.

36. Sefer ha-yashar, introduction, 9.

37. The history of scholarship on R. Tam's personality is interesting in its own right. The third chapter of E. E. Urbach's Tosafists, devoted entirely to R. Tam, begins with the following sentences: "R. Isaac Hirsch Weiss devoted a special monograph to him.... Weiss's description is entirely 
with my article on R. Tam's aforementioned polemic against R. Meshullam of Melun, ${ }^{38}$ I attempt to pierce the fog of R. Tam's stormy personality and address the substance of his debates. It is precisely this substance that is lacking in these earlier indispensable studies.

\author{
Avraham (Rami) Reiner \\ Ben-Gurion University of the Negev
}

apologetic. He attempts to reconcile and answer for [R. Tam's] inconsistency, hubris, and unrestrained tongue, which are obvious to all in R. Tam's words.... In doing so, he manages to soften this dynamic and impulsive personality to such a great degree that the portrait which emerges is of a rabbi who inclines toward leniency and opposes those who are stringent ... in short, the figure of a maskilic rabbi." In his own portrayal, Urbach, in contradistinction, emphasized the unique contours of R. Tam's personality, to the extent that one sometimes gets the sense that Urbach was enamored with this colorful figure and gave up on the possibility of explaining and uniting the statements that seem so disparate. Criticism of Urbach for missing this opportunity is implied in Jacob Katz's review of Urbach's book. See J. Katz, "On Ephraim E. Urbach's 'The Tosafists"” [in Hebrew], in Halakhah and Kabbalah (Jerusalem: Magnes, 1984), 340-49. For a critical assessment of Urbach's approach, see Jacob Sussmann, "The Scholarly Oeuvre of Professor Ephraim Elimelech Urbach," in Ephraim Elimelech Urbach: A Bio-Bibliography, ed. David Asaf, supplement to Jewish Studies 1 (Jerusalem: World Union of Jewish Studies, 1993), 40-42.

38. A. Reiner, "Rabbenu Tam and R. Meshullam," 207-39. 